\title{
Bone Cancer pT3 TNM Finding v7
}

National Cancer Institute

\section{Source}

National Cancer Institute. Bone Cancer pT3 TNM Finding V7. NCI Thesaurus. Code C88430.

Bone cancer with discontinuous tumors in the primary bone site. (from AJCC 7th Ed.) 